\title{
Kepatuhan Bidan dalam Penerapan SOP Pemotongan Tali Pusat pada Bayi Baru Lahir
}

\author{
Rosmadewi $^{1}$, Mugiati ${ }^{2}$ \\ Jurusan Kebidanan, Politeknik Kesehatan Tanjung Karang, Indonesia \\ Email: ros29madewi@gmail.com
}

\begin{abstract}
Midwife Compliance in the Application of SOP Cutting the Umbilical Cord in Newborn Babies. Pinning and cutting the umbilical cord is a standard procedure that is always done when the baby is born. The benefits of delaying cord clamping for infants include the opportunity for red blood, stem cells, and immune cells to be transmitted to the baby's body outside the uterus. As for mothers, delaying cord clamping can reduce the complications of bleeding. This study aims to determine the Midwife's Compliance Level in the Implementation of SOP Cutting the Cord in Newborns in Bandar Lampung City. This type of research is correlation analytic with a cross-sectional approach. The research subjects are midwives who provide birth assistance services in the city of Bandar Lampung with a total of 131 people, the sample in this study was the total population. Data collection uses primary data. Univariate data analysis uses percentages and bivariate analysis uses chi-square. The results showed that midwives' level of compliance in implementing SOP of umbilical cord-cutting in newborns in the category of noncompliance was 83 respondents $(63,4 \%)$, midwife knowledge was categorized as good as 102 respondents $(77,9 \%)$ and the attitude of midwives in the category of no support as many as 76 respondents $(58,02 \%)$. There is a significant relationship between midwives 'attitudes and midwives' compliance in the adoption of umbilical cord cutting SOPs in newborns and there is no relationship between midwives 'knowledge and midwives' level of compliance in implementing umbilical cord cutting SOPs. Professional organizations (IBI Bandar Lampung City) and midwives coordinator of the local health center need to program supervision to midwives who provide delivery assistance to always implement the SOP cutting the umbilical cord on newborns.
\end{abstract}

Keywords: Attitude, Knowledge, Midwife compliance

\begin{abstract}
Abstrak: Kepatuhan Bidan Dalam Penerapan SOP Pemotongan Tali Pusat pada Bayi Baru Lahir. Penjepitan dan pemotongan tali pusat merupakan prosedur standar yang selalu dilakukan saat bayi dilahirkan. Manfaat penundaan penjepitan tali pusat untuk bayi termasuk masih diberinya kesempatan untuk darah merah, sel-sel batang dan sel-sel kekebalan untuk ditransisi ke tubuh bayi di luar rahim. Sedangkan untuk ibu, dengan menunda penjepitan tali pusat ternyata bisa mengurangi komplikasi terjadinya perdarahan. Penelitian ini bertujuan untuk mengetahui tingkat kepatuhan bidan dalam penerapan SOP pemotongan tali pusat pada bayi baru lahir di kota Bandar Lampung. Jenis penelitian ini adalah analitik korelasi dengan pendekatan cross sectional. Subjek penelitian adalah Bidan yang melakukan pelayanan pertolongan persalinan di Kota Bandar Lampung sejumlah 131 orang, sampel dalam penelitian ini total populasi. Pengumpulan data menggunakan data primer. Analisa data univariat menggunakan persentase dan analisa bivariat menggunakan chi square. Hasil penelitian didapatkan tingkat kepatuhan bidan dalam penerapan SOP pemotongan tali pusat pada bayi baru lahir dalam katagori tidak patuh yaitu sebanyak 83 responden $(63,4 \%)$, pengetahuan bidan dikatagorikan baik yaitu 102 responden $(77,9 \%)$ dan sikap bidan dalam katagori tidak mendukung sebanyak 76 responden $(58,02 \%)$. Ada hubungan yang signifikan antara sikap bidan dengan kepatuhan bidan dalam penerapan SOP pemotongan tali pusat pada bayi baru lahir dan tidak ada hubungan antara pengetahuan bidan dengan tingkat kepatuhan bidan dalam penerapan SOP pemotongan tali pusat. Agar organisasi profesi (IBI Kota Bandar Lampung) dan bidan koordinator puskesmas setempat perlu memprogramkan supervisi kepada bidan yang melakukan pertolongan persalinan agar selalu menerapkan SOP pemotongan tali pusat pada bayi baru lahir.
\end{abstract}

Kata kunci: Sikap, Pengetahuan, Kepatuhan bidan 


\section{PENDAHULUAN}

Anemia defisiensi besi pada bayi merupakan masalah kesehatan yang hampir terdapat diseluruh negara berkembang. Anemia defisiensi besi merupakan anemia yang sering terjadi pada bayi dengan kejadian tertinggi pada umur 6 sampai 24 bulan. Tingginya angka prevalensi anemia pada bayi usia 6-9 bulan berhubungan dengan tidak cukupnya penyimpanan cadangan zat besi pada bayi tersebut sehingga dapat mengakibatkan gangguan pertumbuhan dan perkembangan dalam 6 bulan pertama kehidupan dan beberapa faktor post natal yang bisa mengakibatkan penurunan dini pada penyimpanan cadangan zat besi juga dapat menimbulkan anemia.

Masalah anemia defisiensi zat besi pada bayi merupakan masalah kesehatan serius karena akan mengganggu perkembangan mental dan kognitif untuk perkembangan selanjutnya setelah dewasa. Kekurangan zat besi pada lima tahun pertama kehidupan si kecil dapat mengganggu tumbuh kembang sehingga berdampak negatif pada kualitas hidupnya. Anemia yang berkepanjangan pada anak akan mengalami beberapa resiko buruk bagi kesehatan dan pertumbuhannya. Efek anemia bagi bayi dan anak berupa pertumbuhan fisik yang terhambat dan mengganggu perkembangan neurologis anak yang berakibat pada berkurangnya kemampuan belajar dan tingkat IQ yang lebih rendah. Berdasarkan penelitian yang dilakukan terhadap anak penderita anemia berat di Meksiko, mereka mengalami gangguan fungsi motorik yang terlihat dari cara berjalan yang tidak sempurna.

Salah satu pencegahan terhadap hal yang kritis tersebut, penundaan pengkleman tali pusat dapat merupakan strategi yang efektif untuk mencegah anemia dan meningkatkan survival anak (Van Rheenen, 2006). Berdasarkan beberapa penelitian terkini diketahui bahwa tindakan pengkleman tali pusat secepatnya akan mengambil darah bayi 54-160cc. Pengkleman tali pusat sebelum bayi bernafas spontan mengakibatkan suplai darah ke paru paru berkurang sehingga terjadi hipovolemi. Pengkleman tali pusat secepatnya juga meningkatkan resiko bayi terkena anemia.

Waktu penjepitan tali pusat memegang peranan penting dalam menentukan kecukupan zat besi pada bayi baru lahir. Saat dalam kandungan janin berhubungan dengan ibu melalui tali pusat yang merupakan bagian dari plasenta. Sekitar $25 \%$ sampai $60 \%$ volume darah fetoplacental berada dalam plasenta yang dialirkan ke bayi sampai dengan tali pusat berhenti berdenyut (disebut transfuse plasenta). Transfusi plasenta yang berhubungan dengan penundaan penjepitan tali pusat dapat menambah $30 \%$ volume darah dan $60 \%$ sel darah merah. Jumlah eritrosit dan hemoglobin yang cukup selanjutnya dapat dijadikan sumber zat besi bagi bayi (Agustini, Rosalina, Roeslani, 2016).

Penjepitan dan pemotongan tali pusat merupakan prosedur standar yang selalu dilakukan saat bayi dilahirkan. Manfaat penundaan penjepitan tali pusat untuk bayi termasuk masih diberinya kesempatan untuk darah merah, sel-sel batang dan sel-sel kekebalan untuk ditransisi ke tubuh bayi di luar rahim. Sedangkan untuk ibu, dengan menunda penjepitan tali pusat ternyata bisa mengurangi komplikasi terjadinya perdarahan.

Dr. Judith Mercer adalah seorang ahli terkemuka yang telah melakukan penelitian dan mempunyai bukti mengenai manfaat penundaan penjepitan talipusat baik untuk bayi aterm maupun bayi prematur. Dengan review dari literatur yang tersedia menunjukkan bahwa penjepitan tali pusat yang tertunda dapat membuat kadar hematokrit yang lebih tinggi, transportasi oksigen lebih optimal dan aliran sel darah merah yang lebih tinggi ke organ vital, anemia bayi berkurang dan meningkatkan durasi menyusui. Dr. Judith Mercer, dkk juga telah meneliti manfaat pentingnya penundaan penjepitan talipusat untuk memaksimalkan volume darah untuk masa transisi janin ke masa neonatal (Mercer, dkk., 2001).

Penelitian terbaru menyatakan bahwa penjepitan tali pusat segera (dalam 5-10 detik), bila dibandingkan dengan penjepitan tali pusat yang tertunda ternyata menimbulkan penurunan 20-40ml darah perkilogram berat badan yang setara dengan 30-35 mg zat besi. Telah diperdebatkan bahwa penjepitan pada tali pusat dengan segera akan menyebabkan meningkatnya risiko hipovolemia dan kehilangan zat besi, serta kehilangan hematopoietik sel induk. Pemotongan tali pusat segera dicurigai sebagai penyebab utama anemia pada bayi baru lahir, sehingga hal ini menyebabkan beberapa peneliti merekomendasikan untuk menunda penejepitan pada tali pusat sebagai intervensi yang murah untuk mengurangi kejadian utama pada 6 bulan pertama kehidupan.

Berdasarkan dari beberapa penelitian terkini diketahui bahwa tindakan penjepitan tali pusat secepatnya akan mengambil darah bayi 54$160 \mathrm{cc}$, yang artinya setengah lebih volume darah total bayi. Penjepitan tali pusat sebelum bernafas mengakibatkan suplai darah ke paru paru berkurang sehingga terjadi hipovolemi. 
Penjepitan tali pusat secepatnya juga meningkatkan resiko bayi terkena anemia.

Pada bayi normal, Kementerian Kesehatan RI telah melakukan sosialisasi penjepitan tali pusat dilakukan setelah 2 menit bayi lahir (saat lahir diletakan diatas perut ibu), kemudian diberikan oksitosin 10 unit dalam 1 menit pertama setelah bayi lahir dan kemudian dilakukan penjepitan tali pusat (Kementerian Kesehatan RI, 2010).

Penatalaksanaan bayi baru lahir, dalam hal ini penjepitan tali pusat berdasarkan standar pelayanan yang telah ditetapkan yaitu setelah denyutan tali pusat terhenti atau 2 menit setelah lahir dapat mencegah terjadinya anemia pada bayi baru lahir. Pada 60 langkah prosedur Asuhan Persalinan Normal (JNPK-KR, 2017), pengkleman tali pusat merupakan langkah ke 30 . Tali pusat di klem dan dipotong setelah dua menit bayi lahir, lakukan terlebih dahulu penyuntikan oksitosin 10 menit dalam waktu 1 menit, sebelum tali pusat dipotong.

Pelayanan pada bayi baru lahir merupakan salah satu penerapan peran dan fungsi bidan sebagai pelaksana asuhan kebidanan pada ibu dan anak. Kompetensi bidan yang meliputi pendidikan, pengetahuan dan ketrampilan harus dimiliki oleh bidan dalam melaksanakan praktik kebidanan secara aman dan bertanggung jawab pada berbagai tatanan pelayanan kesehatan (Ikatan Bidan Indonesia, 2006).

Terdapat cukup bukti yang menunjukkan masih rendahnya kualitas pelayanan kesehatan di tingkat masyarakat, seperti studi yang dilakukan di Indonesia oleh D'Ambruoso, et al (2009) yang menyatakan bahwa pelayanan kebidanan yang diberikan oleh bidan masih di bawah standar pelayanan. Pelayanan dikatakan telah memenuhi standar apabila didalam pelaksanaannya mengacu kepada aturan yang telah diatur dengan jelas yang diterbitkan oleh organisasi yang berwenang.

Bidan sebagai tenaga profesional dalam pelayanan kesehatan ibu dan anak wajib mematuhi standar pelayanan kebidanan. Kepatuhan bidan menerapkan standar pemotongan tali pusat pada bayi baru lahir berdampak dan mempunyai daya ungkit terhadap kualitas pelayanan bayi baru lahir yang selanjutnya berkontribusi terhadap penurunan angka morbiditas dan mortalitas pada bayi. Perubahan sikap dan perilaku individu dimulai dengan tahap kepatuhan, identifikasi dan internalisasi. Perilaku individu dalam organisasi dipengaruhi oleh karakteristik individu (kemampuan, kebutuhan, kepercayaan, pengalaman, pengharapan dan lainnya) dan karakteristik organisasi (hierarki, tugas-tugas, wewenang, tanggung jawab, sistem reward, pembinaan dan sistem kontrol).

Seseorang dikatakan patuh apabila ia dapat memahami, menyadari dan menjalankan peraturan yang telah ditetapkan, tanpa paksaan dari siapapun. Karakter individu bidan diantaranya motivasi dan didukung oleh faktor organisasi seperti kualitas supervisi dapat menunjang profesionalisme bidan dalam kepatuhan melakukan penjepitan tali pusat tertunda pada bayi baru lahir. Selain itu juga, dengan motivasi bidan akan memiliki semangat tinggi dalam melaksanakan pelayanan kebidanan, tanpa adanya motivasi, seorang bidan tidak dapat mematuhi standar dalam praktik kebidanan atau bahkan dibawah standar praktik.

Bidan Koordinator (Bikor) melakukan pembinaan klinis profesi bidan kepada seluruh bidan sesuai wilayah kerjanya mencakup bidan desa, bidan puskesmas, bidan praktik mandiri dan bidan yang bekerja di rumah sakit. Supervisi yang dilakukan dengan baik oleh Bikor adalah penyeliaan yang dijalankan secara efektif dan bersifat fasilitatif, tidak mengagetkan atau mencari-cari kesalahan bidan. Supervisi fasilitatif menuntut bikor mempunyai ketrampilan dalam berkomunikasi, membantu memecahkan masalah, membangun kerja sama tim serta membimbing dan mengarahkan bidan yang disupervisi kearah praktik terbaik dan memenuhi standar. Supervisi fasilitatif dilakukan secara terarah dengan alat bantu daftar tilik penyeliaan sehingga proses supervisi dapat dilakukan secara terukur dan sistematis (Kementerian Kesehatan RI, 2010).

Berdasarkan studi pendahuluan yang penulis lakukan kepada ketua Ikatan Bidan Indonesia (IBI) Cabang Kota Bandar Lampung, bahwa bidan yang melaksanakan praktik kebidanan, 93\% dengan latar belakang pendidikan D III dan D IV Kebidanan yang pada masa studinya telah mendapatkan ilmu tentang tindakan penundaan penjepitan tali pusat, namun dalam pelaksanaan pertolongan persalinan sampai saat ini belum diketahui tentang kepatuhan bidan dalam menerapkan tindakan penundaan penjepitan tali pusat di Kota Bandar Lampung .

Berdasarkan latar belakang di atas peneliti tertarik untuk menegtahui tingkat kepatuhan bidan dalam penerapan SOP pemotongan tali pusat pada bayi baru lahir di Kota Bandar Lampung. 


\section{METODE}

Jenis penelitian yang digunakan merupakan penelitian kuantitatif korelasi dengan pendekatan cross sectional. Penelitian dilakukan pada bulan Juni sampai dengan Oktober tahun 2016 di Kota Bandar Lampung. Populasi dalam penelitian ini adalah Bidan yang melakukan pelayanan pertolongan persalinan di Kota Bandar Lampung sejumlah 126 orang. Sampel yang digunakan dalam penelitian ini adalah total populasi. Kriteria Inklusi sampel adalah sebagai Bidan yang melakukan pertolongan persalinan/praktik kebidanan, tidak sedang pendidikan lanjut, tidak sedang cuti bekerja, sehat dan bayi yang dilahirkan normal/tidak prematur. Sedangkan kriteria eksklusi adalah sebagai bidan tidak melakukan pertolongan persalinan/praktik kebidanan, sedang melaksanakan pendidikan lanjut, sedang cuti bekerja atau dirawat di rumah sakit dan bayi yang dilahirkan prematur. Responden yang diambil sebagai sampel penelitian adalah bidan yang telah melakukan praktik pertolongan persalinan lebih dari 2 tahun, pendidikan minimal D III Kebidanan, usia antara 25-60 tahun. Pertolongan persalinan yang dilakukan oleh bidan di Bidan Praktik Mandiri, Klinik Bersalin atau Puskesmas Rawat Inap.

Data yang dikumpulkan menggunakan data primer yaitu data yang diambil langsung dari responden. Data yang dikumpulkan menggunakan alat pengumpul data, berupa tes untuk mengukur data pengetahuan. Sedangkan kuisioner, untuk mengukur sikap dan kepatuhan bidan dalam penerapan SOP pemotongan tali pusat. Data tingkat pengetahuan bidan tentang standar pemotongan tali pusat didapatkan dengan cara menyebarkan soal yang ada hubungannya dengan pemotongan tali pusat kepada responden dan responden diminta untuk menjawabnya. Sedangkan data sikap dan kepatuhan bidan dalam penerapan standar pemotongan tali pusat didapatkan dengan cara membagikan kuesioner kepada responden. Kuesioner tersebut berisi pernyataan-pernyataan tentang standar pemotongan tali pusat dan perilaku-perilaku bidan dalam menerapkan standar pemotongan tali pusat untuk mengetahui kepatuhan bidan.

Pengolahan data dilakukan dengan cara editing, coding, processing dan cleaning. Analisis data dapat dibagi menjadi dua tahapan yaitu analisis univariat dengan prosentase dan analisis bivariat dengan chi square.

Penelitian ini telah mendapatkan Persetujuan Etik Penelitian Kesehatan (Ethical Clearance) Nomor: LB.02.01/I.1/3081.3/2016 dari Komisi Etik Penelitian Kesehatan Politeknik Kesehatan Kementerian Kesehatan Tanjung Karang.

\section{HASIL}

Tabel 1. Distribusi Responden Berdasarkan Usia, Pendidikan, Tingkat Kepatuhan Bidan, Pengetahuan dan Sikap

\begin{tabular}{llrr}
\hline \multirow{2}{*}{ Variabel } & \multicolumn{2}{c}{ Jumlah } \\
\cline { 3 - 4 } & & \multicolumn{1}{c}{$\mathbf{n}$} & \multicolumn{1}{c}{$\%$} \\
\hline \multirow{3}{*}{ Usia } & $\leq 25$ tahun & 7 & 5,55 \\
& 26-50 tahun & 109 & 86,51 \\
& $>50$ tahun & 10 & 7,94 \\
\hline \multirow{3}{*}{ Pendidikan } & D1 Kebidanan & 5 & 3,97 \\
& D III Kebidanan & 76 & 60,32 \\
& D IV Kebidanan & 45 & 35,71 \\
\hline Tingkat & Tidak Patuh & 78 & 61,9 \\
Kepatuhan & Patuh & 48 & 38,1 \\
\hline \multirow{2}{*}{ Pengetahuan } & Kurang baik & 50 & 39,7 \\
& Baik & 76 & 60,3 \\
\hline \multirow{4}{*}{ Sikap } & Negatif (Tidak & 72 & 57,1 \\
& mendukung) & & \\
& Positif & & \\
& (Mendukung) & 54 & 42,9 \\
\hline \multirow{2}{*}{} & & \multicolumn{2}{c}{}
\end{tabular}

Berdasarkan tabel 1, sebagaian besar usia responden adalah 26-50 tahun $109(86,51 \%)$, pendidikan responden D III Kebidanan 76 $(60,32 \%)$, Tingkat Kepatuhan adalah tidak patuh $78(61,9 \%)$, Pengetahuannya baik $76(60,3 \%)$ dan sikapnya negatif/tidak mendukung $72(57,1 \%)$.

Tabel 2. Hubungan Pengetahuan dan Sikap dengan Tingkat Kepatuhan Bidan terhadap SOP Pemotongan Tali Pusat

\begin{tabular}{|c|c|c|c|c|c|c|c|c|}
\hline \multirow{3}{*}{$\begin{array}{l}\text { Variabel } \\
\text { Pengetahuan } \\
\end{array}$} & \multicolumn{4}{|c|}{ Tingkat Kepatuhan } & \multirow{2}{*}{\multicolumn{2}{|c|}{ Total }} & \multirow{3}{*}{ p-value } & \multirow{3}{*}{ OR 95\%CI } \\
\hline & \multicolumn{2}{|c|}{ Tidak Patuh } & \multicolumn{2}{|c|}{ Patuh } & & & & \\
\hline & n & $\%$ & $\mathbf{n}$ & $\%$ & $\mathbf{n}$ & $\%$ & & \\
\hline Kurang Baik & 28 & 56 & 22 & 44 & 50 & 100 & 0,146 & \\
\hline Baik & 50 & 65,79 & 26 & 34,21 & 76 & 100 & & \\
\hline \multicolumn{9}{|l|}{ Sikap } \\
\hline Negatif (Tidak Mendukung) & 44 & 61,11 & 28 & 38,89 & 72 & 100 & 0,001 & 924(446-191) \\
\hline Positif (Mendukung) & 34 & 62,96 & 20 & 37,04 & 54 & 100 & & \\
\hline
\end{tabular}


Berdasarkan tabel 2 diperoleh bahwa dari 50 orang bidan yang memiliki pengetahuan yang kurang baik $28(56 \%)$ tidak patuh terhadap SOP pemotongan tali pusat dan $22(44 \%)$ patuh terhadap SOP pemotongan tali pusat. Hasil uji statistik diperoleh nilai $p$-value 0,846 sehingga $p$ value $>\alpha(0,05)$, maka Ho gagal ditolak, yang berarti secara statistik tidak ada hubungan antara pengetahuan dengan tingkat kepatuhan bidan dan dalam penerapan SOP pemotongan tali pusat di Wilayah Kota Bandar Lampung tahun 2016.

Selanjutnya dari 72 orang yang tidak mendukung terhadap SOP pemotongan tali pusat, 44 orang $(61,11 \%)$ tidak patuh terhadap SOP pemotongan tali pusat dan 28 orang $(38,89 \%)$ patuh terhadap SOP pemotongan tali pusat. Hasil uji statistik diperoleh nilai $p$-value 0,001 sehingga $p$-value $<\alpha(0,05)$, maka Ho ditolak, yang berarti secara statistik ada hubungan antara sikap dengan tingkat kepatuhan bidan dalam penerapan SOP pemotongan tali pusat pada bayi baru lahir di Wilayah Kota Bandar Lampung.

\section{PEMBAHASAN}

\section{Kepatuhan}

Berdasarkan hasil penelitian, didapatkan bahwa sebagian besar bidan tidak patuh $(61,9 \%)$ dalam melakukan pemotongan tali pusat pada bayi bayi baru lahir sesuai dengan SOP.

Menurut rekomendasi WHO, disarankan untuk menunda pemotongan tali pusat $1-3$ menit setelah persalinan. Tujuannya agar darah terus mengalir dari plasenta ke bayi. Dalam plasenta yang masih berdenyut terdapat $30-60 \%$ darah tambahan untuk bayi. Manfaat penundaan pemotongan tali pusat seperti ini dapat menurunkan risiko anemia pada bayi. Selain itu darah yang masih mengalir dari plasenta meningkatkan kandungan zat besi bayi hingga enam bulan setelah lahir. Aliran sel-sel induk dari plasenta juga mampu membantu menyempurnakan organ dalam tubuh bayi.

Menurut penulis responden tidak patuh terhadap penundaan pemotongan tali pusat karena responden belum memahami benar kegunaan penundaan tali pusat. Oleh karena itu perlu dilakukan penegasan kembali tentang penerapan SOP pemotongan tali pusat pada bayi baru lahir.

\section{Pengetahuan}

Berdasarkan hasil penelitian,
pengetahuan responden tentang standar operational pemotongan tali pusat pada bayi baru lahir dalam katagori baik $(60,3 \%)$.

Pengetahuan memegang peranan penting dalam menentukan keputusan responden dalam melakukan pemotongan tali pusat tertunda. Pengetahuan merupakan dasar dari penerimaan persuasi petugas kesehatan sebelum terjadinya pengambilan keputusan (decision) dan tahap konfirmasi (confirmation) dari suatu keputusan melakukan suatu tindakan (Notoatmodjo, 2007).

Pengetahuan tentang SOP pemotongan tali pusat pada penelitian ini dalam katagori baik karena responden dengan latar belakang pendidikan D III Kebidanan dan D IV Kebidanan yang pada masa pendidikannya telah mendapat mata kuliah tentang asuhan kebidanan pada ibu bersalin dan bayi baru lahir. Selain itu juga didalam kurikulum telah dikenalkan tentang asuhan persalinan normal yang pada langkahlangkah penatalaksanaannya dicantumkan tentang penundaan pemotongan tali pusat sampai teli pusat berhenti berdenyut/1-3 menit setelah bayi lahir.

Namun masih ditemukan pengetahuan responden yang kurang baik $(39,7 \%)$. Hal ini yang memungkinkan responden tidak patuh dalam menerapkan SOP pemotongan tali pusat karena responden tidak memahami tentang dampak pemotongan tali pusat yang tidak ditunda. Oleh karena itu perlu penyegaran kembali tentang evidance based pemotongan tali pusat.

\section{Sikap}

Berdasarkan hasil penelitian sebagian besar sikap responden dalam katagori negatif/tidak mendukung $(57,1 \%)$.

Sikap seseorang terhadap suatu objek adalah perasaan mendukung atau memihak maupun perasaan tidak mendukung atau tidak memihak pada objek tersebut (Berkowit dalam Azwar, 2013).

Pada penelitian ini sikap responden tidak mendukung terhadap penatalaksanaan pemotongan tali pusat yang tertunda karena responden belum memahami tentang manfaat penundaan pemotongan tali pusat dalam rangka pencegahan terjadinya anemia pada bayi yang akan berdampak terhadap kesehatan bayi. Oleh karena itu pengurus IBI wilayah Kota Bandar Lampung perlu memberikan support kepada 
anggotanya yang melakukan pertolongan persalinan agar melakukan pemotongan tali pusat sesuai dengan SOP.

\section{Hubungan Pengetahuan dengan Tingkat Kepatuhan Bidan dalam Penerapan SOP Pemotongan Tali Pusat}

Hasil penelitian didapatkan bahwa tidak ada hubungan antara pengetahuan dengan kepatuhan bidan dalam penerapan SOP pemotongan tali pusat pada bayi baru lahir di Kota Bandar Lampung. Hasil penelitian ini tidak sesuai dengan teori menurut pendapat Notoatmodjo (2007) bahwa sebagian besar pengetahuan atau kognitif merupakan domain yang sangat penting untuk terbentuknya tindakan seseorang (over behavior) karena perilaku baru didasari oleh pengetahuan.

Hal ini juga tidak sejalan dengan penelitian Wijayanti dan Erry (2018), yang mengatakan bahwa ada hubungan antara pengetahuan bidan tentang standar antenatal care dengan pelaksanaan antenatal care $14 \mathrm{~T}$. Namun, hasil penelitian ini sejalan dengan penelitian Rahmi (2010) yang menyatakan bahwa tidak ada hubungan bermakna antara pengetahuan dengan perilaku orang tua terhadap anak dengan penyakit jantung bawaan dengan $r=0,216$. Selain itu juga penelitian Tulus, dkk (2014) menyatakan bahwa tidak ada hubungan pengetahuan dengan terjadinya keputihan dengan $p$-value 1,000 .

Pengetahuan bidan di Kota Bandar Lampung tentang SOP pemotongan tali pusat sebagian besar sudah baik karena latar belakang pendidikannya adalah Diploma III dan Diploma IV Kebidanan yang dalam masa pendidikannya sudah banyak terpapar tentang standar dalam pemotongan tali pusat melalui pembelajaran mata kuliah Asuhan Kebidanan Pada Persalinan yang didalamnya terdapat pokok bahasan Asuhan Persalinan Normal (APN) yang didalamnya terdapat langkah dalam pemotongan tali pusat tertunda. Selain itu juga bidan di Kota Bandar Lampung sudah diikutkan sosialisasi tentang penatalaksanaan bayi baru lahir normal, namun dalam penatalaksanaan bayi baru lahir belum semua bidan menerapkan SOP pemotongan tali pusat tersebut.

Menurut Notoatmodjo (2007) pengetahuan dipengaruhi oleh dua faktor yakni faktor internal dan faktor eksternal. Adapun faktor internal terdiri dari pendidikan, minat, pengalaman dan usia. Sedangkan faktor eksternal terdiri dari ekonomi dan kebudayaan.

Pengetahuan bidan tentang SOP pemotongan tali pusat belum sepenuhnya diterapkan dalam penatalaksanaan bayi baru lahir karena bidan belum menyadari akan dampak pemotongan tali pusat segera terhadap kejadian anemia bayi baru lahir yang dapat mengakibatkan berkurangnya jumlah darah dari tranfusi plasenta, dimana transfusi plasenta mengalirkan darah saat menunda penjepitan tali pusat yang memiliki sangat banyak manfaat. Defisiensi zat besi pada beberapa bulan pertama kehidupan berhubungan dengan keterlambatan perkembangan saraf, terutama pada syaraf yang dapat irreversibel.

Beberapa keuntungan penundaan penjepitan tali pusat diantaranya meningkatkan respon adaptasi kardio-pulmo bayi, meningkatkan tekanan darah bayi, meningkatkan aliran sel darah metah dan transport oksigen dan mencegah terjadinya anemia defisiensi besi. Penundaan penjepitan tali pusat juga dapat membantu kontak awal antara ibu dan anak. ${ }^{1}$ Beberapa efek menguntungkan dari penundaan penjepitan tali pusat adalah meningkatkan haemopoetic stem cells yang ditransfer ke bayi.

Kejadian anemia pada bayi dapat menghambat proses tumbuh kembang bayi yang berdampak pada gangguan kecerdasan yang sangat berperan pada kualitas generasi mendatang yang sangat diperlukan dalam menyongsong era globalisasi yang segala sesuatunya berkaitan dengan pengembangan tekhnologi.

Oleh karena itu perlu adanya penyegaran secara terus menerus kepada bidan tentang pentingnya kualitas generasi dimasa yang akan datang yang salah satunya merupakan tanggung jawab bidan selaku penolong dalam persalinan. Selain itu juga perlu adanya pengulangan kembali tentang SOP pemotongan tali pusat pada bayi baru lahir pada setiap pertemuan yang melibatkan bidan, sehingga bidan merasa hal tersebut merupakan salah satu hal kewajiban yang harus dilakukan dalam setiap pertolongan persalinannya.

\section{Hubungan Sikap dengan Tingkat Kepatuhan Bidan dalam Penerapan SOP Pemotongan Tali Pusat}

Hasil penelitian didapatkan bahwa ada hubungan antara sikap dengan kepatuhan dalam menerapkan SOP pemotongan tali pusat pada bayi baru lahir. Sikap bidan tentang penerapan SOP pemotongan tali pusat yang didukung pengetahuan yang memadai tentunya akan menunjang perilaku bidan dalam melakukan penatalaksanaan bayi baru lahir yang berkualitas. Hal ini sesuai dengan teori Green dalam Notoatmojo (2007) bahwa tingkat pengetahuan 
merupakan predisposisi dalam perilaku positif karena dengan pengetahuan seseorang akan mulai mengenal dan mencoba atau melakukan suatu tindakan.

Selanjutnya hasil penelitian ini sejalan dengan penelitian Sriningsih (2010), yang mengatakan bahwa ada hubungan antara sikap bidan tentang standar antenatal care dengan jumlah kunjungan ibu hamil dalam pemeriksaan antenatal. Selain itu juga, hasil penelitian Sari (2012), menyatakan bahwa ada hubungan yang bermakna antara sikap dengan perilaku kesehatan reproduksi dengan $p$-value 0,003 . Hasil penelitian Aritonang (2015) menyatakan ada hubungan yang signifikan antara sikap tentang kesehatan reproduksi dengan perilaku seks pranikah pada remaja usia 15-17 tahun.

Sikap bidan di Kota Bandar Lampung sebagian besar belum mendukung tentang penerapan SOP pemotongan tali pusat pada bayi baru lahir. Sikap bidan tentang penerapan standar pemotongan tali pusat pada bayi baru lahir merupakan bagian dari perilaku tenaga kesehatan khususnya bidan. Bidan pada saat melakukan pertolongan persalinan seharusnya menerapkan standar operasional prosedur (SOP) pemotongan tali pusat yaitu dilakukan setelah tali pusat berhenti berdenyut atau 2 menit setelah bayi baru lahir. Standar ini telah tertuang dalam Protokol Asuhan Neonatal (PONEK, 2008), Buku Saku Pelayanan Kesehatan Neonatal Essensial (Kementerian Kesehatan RI, 2010) dan Asuhan Persalinan Normal (JNPK-KR, 2017).

Sikap negatif pada penelitian ini, ditunjukkan bila bidan tidak mau menerapkan SOP pemotongan tali pusat yaitu melakukan penundaan penjepitan tali pusat minimal 2 menit setelah bayi lahir. Berdasarkan pendapat di atas, peneliti memberikan pandangan bahwa sikap merupakan faktor predisposisi yang mencakup komponen seperti keyakinan, ide, konsep serta ungkapan emosional yang diekspresikan dengan tingkah laku yang berkaitan untuk bertindak, sehingga dapat disimpulkan bahwa bila penolong persalinan memiliki sikap yang positif (mendukung) terhadap prosedur penjepitan dan pemotongan tali pusat maka kecil kemungkinan untuk melakukan pelanggaran terhadap prosedur penjepitan dan pemotongan tali pusat dan begitu juga sebaliknya.

Oleh karena itu agar setiap penolong persalinan mau menerapkan penundaan penjepitan dan pemotongan tali pusat, perlu adanya supervisi dari organisasi profesi dan Puskesmas setempat melalui bidan koordinator ke tempat bidan yang melakukan pertolongan persalinan di rumah maupun di pelayanan kesehatan agar bidan selalu menerapkan SOP pemotongan tali pusat pada bayi baru lahir pada setiap melakukan pertolongan persalinan sehingga dapat mencegah terjadinya anemia pada bayi baru lahir yang berdampak pada kualitas generasi di masa yang akan datang.

\section{SIMPULAN}

Berdasarkan hasil penelitian dapat diambil kesimpulan tidak ada hubungan antara pengetahuan bidan dengan kepatuhan bidan dalam penerapan SOP pemotongan tali pusat pada bayi baru lahir di Wilayah Kota Bandar Lampung tahun 2016, ada hubungan antara sikap bidan dengan kepatuhan bidan dalam penerapan SOP pemotongan tali pusat pada bayi baru lahir di Kota Bandar Lampung tahun 2016.

Oleh karena itu diharapkan agar organisasi profesi (IBI Kota Bandar Lampung) dan bidan koordinator puskesmas setempat perlu memprogramkan supervisi kepada bidan yang melakukan pertolongan persalinan agar selalu menerapkan SOP pemotongan tali pusat pada bayi baru lahir.

\section{DAFTAR PUSTAKA}

Agustini, S., \& Roeslani, R. D. (2016). Penundaan Penjepitan Tali Pusat pada Bayi Baru Lahir Cukup Bulan. Sari Pediatri, 17(5), 384-390.

Aritonang Y.S. (2015). Hubungan Pengetahuan Dan Sikap Tentang Kesehatan Reproduksi Dengan Perilaku Seks Pranikah Pada Remaja Usia (15-17 Tahun) Di SMK Yadika 13 Tambun, Bekasi. Jurnal Ilmiah Widya, Volume 3 Nomor 2.

Azwar S. (2013). Sikap Manusia: Teori dan Pengukurannya. Yogyakarta: Pustaka Pelajar.

D'Ambruoso, L., Achadi, E., Adisasmita, A., Izati, Y., Makowiecka, K., \& Hussein, J. (2009). Assessing quality of care provided by Indonesian village midwives with a confidential enquiry. Midwifery, 25(5), 528-539. 
Ikatan Bidan Indonesia. 2006. Bidan Menyongsong Masa Depan-IBI 50 tahun. Jakarta: Depkes RI.

JNPK-KR. 2017. Buku Acuan Persalinan Normal. Jakarta.

Kementerian Kesehatan R.I, 2010. Buku Saku Pelayanan Kesehatan Neonatal Essensial. Pedoman Teknis Pelayanan Kesehatan Dasar. Jakarta. Edisi Revisi.

Mercer J, 2001. Current Best Evidence: A Review Of The Literature On Umbilical Cord Clamping. ÂJ Midwifery Womens Health; 46(6):402-14.

Notoatmodjo Soekidjo. (2007). Perilaku Kesehatan. Jakarta: Rineka Cipta.

Pelayanan Obstetri dan Neonatal Emergensi, Komprehensif (PONEK). (2008). Protokol Asuhan Neonatal. Jakarta, 477 halaman.

Rahmi, N.A. (2010). Hubungan Pengetahuan Orang Tua Dengan Perilaku Kesehatan Dan Anak Dengan Penyakit Jantung Bawaan. [Skripsi]. Semarang: Universitas Diponegoro.

Sari, Yunita. (2012). Hubungan Pengetahuan dan Sikap Terhadap Perilaku Kesehatan
Reproduksi Pada Siswa-Siswi SMA Swasta "X" Di Kota Bandung. [Skripsi]. Bandung: Universitas Kristen Maranatha.

Sriningsih. (2010). Hubungan Pengetahuan Dan Sikap Bidan Tentang Penerapan Standar Antenatal Care Dengan Jumlah Kunjungan Ibu Hamil Dalam Pemeriksaan Antenatal Di Wilayah Kabupaten Kulonprogo. [Tesis]. Surakarta: Universitas Sebelas Maret.

Tulus, C. W. K., Kundre, R. M., \& Bataha, Y. B. (2014). Hubungan Pengetahuan dan Perilaku Dengan Terjadinya Keputihan Pada Remaja Putri Kelas XI Di SMA Kristen 1 Tomohon. JURNAL KEPERAWATAN, 2(2).

Van Rheene PF, Brabin BJ, 2006. Pendekatan Praktis Terhadap Waktu Penjepitan Tali Pusat dalam Keadaan Sumberdaya Yang Buruk. BMJ; 335:954-7.

Wijayanti, W., \& Pramesti, E. D. (2018). Studi Korelasi Pengetahuan Bidan tentang Standar Pelayanan Antenatal dengan Pelaksanaan Antenatal Care 14 T. Proceeding of The URECOL, 638-646. 